\title{
The Art and Science of Nursing Education / L'art et la science de la formation infirmière
}

Florence Myrick

amyrick@ualberta.ca

Jacinthe I. Pepin

Université de Montréal, jacinthe.pepin@umontreal.ca

Follow this and additional works at: https://qane-afı.casn.ca/journal

Part of the Educational Leadership Commons, Higher Education Commons, and the Nursing Commons

\section{Recommended Citation}

Myrick, Florence and Pepin, Jacinthe I. (2015) "The Art and Science of Nursing Education / L'art et la science de la formation infırmière," Quality Advancement in Nursing Education - Avancées en formation infirmière: Vol. 1: Iss. 2, Article 1.

DOI: https://doi.org/10.17483/2368-6669.1042

This Editorial is brought to you for free and open access by Quality Advancement in Nursing Education - Avancées en formation infirmière. It has been accepted for inclusion in Quality Advancement in Nursing Education - Avancées en formation infirmière by an authorized editor of Quality Advancement in Nursing Education - Avancées en formation infirmière. 


\section{The Art and Science of Nursing Education}

As co-editors of this journal, we are pleased to welcome you to the second edition of Quality Advancement in Nursing Education / Avancées en formation infirmière. Through its manuscripts, this journal is committed to supporting an ongoing quest for the enhancement of teaching and learning, and ultimately the advancement of nursing education for quality nursing practices.

When we reflect on the role of the nurse educator, rarely is it viewed from the perspective of art and science. However, when one pauses to reflect, one quickly comes to realize that the role of the educator actually involves the day-to-day process of drawing on the science of nursing education to foster the art of teaching and learning to prepare future clinicians, educators, administrators, and researchers for their professional practice. The contribution nurse educators thus make in engaging in the process of advancing quality nursing education and ultimately enhancing patient care is not to be underestimated, for it all begins with the "Educator". Invariably, it is the Educator who opens the door to the nursing profession for its future practitioners, thereby planting the seed for ensuing practices. And, most importantly, it is the diligent support of the educator that is so critical to success in the role.

For this reason, a journal such as Quality Advancement in Nursing Education / Avancées en formation infirmière is integral to the support and development of nurse educators who engage in the art and science of nursing education and the scholarship of teaching and learning. It is through the generation of empirical evidence that we advance the science of nursing education and ongoing discourse, thus expanding and enhancing our art of teaching. This journal provides a forum in which we have an opportunity to explore and reflect upon the current topics germane to our science and our art, and through this process we can contribute to an optimal learning environment for students. It is only in such an environment that we can support the professional development of students who will graduate as competent, confident and reflexive practitioners.

With the knowledge that is provided through the manuscripts published in this journal, it is our hope that we can further extend our thinking about the many issues that continue to emerge in educating for today's health care climate. A diversity of issues are thus reflected in the second volume and include integrating global citizenship into nursing education practice; focusing on rural nursing educational contexts; a Scholar Practitioner Program (SPP); a digital view of preparing students through the use of preceptorship for rural nursing; and a study reflecting the voices of students and nurses with regard to the relevance of technology and mathematics as specific preparation for today's professional nurse.

Reiterating our first editorial, today's challenges to nursing education are indeed numerous, complex, and diverse. The world is changing and thereby nursing education is changing--particularly in light of what can only be described as the tsunami of technology (Caplan, Myrick, Smitten \& Kelly, 2014). The opportunity to engage in scholarly dialogue is, more than ever, critical to our evolution as nurse educators if we are to satisfactorily meet these many diverse and complex challenges of today's world. We invite you to participate with passion, compassion, knowledge, reflexivity, and open-mindedness. education.

We look forward to an ongoing rich dialogue on quality advancement in nursing 


\section{L'art et la science de la formation infirmière}

À titre de corédactrices en chef, nous sommes heureuses de vous présenter le deuxième numéro de Quality Advancement in Nursing Education / Avancées en formation infirmière. Grâce à la publication d'articles dans cette revue, l'équipe de rédaction s'engage à continuellement soutenir les efforts d'amélioration de l'enseignement et de l'apprentissage, qui visent ultimement l'excellence en formation infirmière pour des pratiques infirmières de qualité.

Lorsque nous pensons aux infirmières enseignantes, nous considérons rarement leur rôle sous l'angle de l'art et de la science. Toutefois, en y réfléchissant bien, on réalise rapidement que le rôle de formatrice repose sur le processus quotidien qui consiste à s'inspirer de la science de la formation infirmière pour la mettre au service de l'art d'enseigner et de soutenir l'apprentissage des futures cliniciennes, formatrices, administratrices et chercheuses en vue de les préparer à exercer leur pratique professionnelle. C'est pourquoi la contribution des infirmières formatrices à l'avancement d'une formation infirmière de qualité, et ultimement à l'amélioration des soins aux patients, ne doit pas être sous-estimée. Tout débute par « la formatrice ». Invariablement, c'est elle qui ouvre la voie à la profession infirmière aux futures cliniciennes et qui, par conséquent, sème les pratiques potentielles qui en découleront. Et plus important encore, le soutien assidu de la formatrice sera déterminant pour leur réussite.

Une revue comme Advancement in Nursing Education / Avancées en formation infirmière fait donc partie intégrante du soutien et du perfectionnement des infirmières formatrices qui s'engagent à conjuguer l'art et la science de la formation infirmière et à contribuer au développement de connaissances sur l'enseignement et l'apprentissage. C'est par la production de résultats de recherche que nous faisons progresser la science de la formation infirmière et par la participation au discours continu que nous faisons évoluer l'art de l'enseignement. Cette revue se veut un forum qui donne l'occasion d'explorer et approfondir les questions saillantes et pertinentes à notre science et notre art. Ainsi, grâce à ce processus nous pouvons contribuer à créer un milieu d'apprentissage optimal pour les étudiantes. C'est seulement dans un tel environnement que nous pouvons favoriser le développement professionnel d'étudiantes qui deviendront des cliniciennes compétentes, confiantes et réfléchies.

Grâce aux connaissances que contiennent les articles publiés dans cette revue, nous espérons continuer de stimuler la réflexion sur de nombreuses questions qui ne cessent de surgir dans la formation en sciences infirmières dans le contexte des soins de santé d'aujourd'hui. Diverses questions sont donc traitées dans ce deuxième numéro, incluant l'intégration de la citoyenneté globale dans la pratique éducative en sciences infirmière; l'apprentissage réalisé en contextes ruraux de formation; un programme de cliniciennes scientifiques; le numérique dans la préparation des étudiantes en sciences infirmières en milieu rural à l'aide du préceptorat; et une étude reflétant les voix étudiantes et infirmières sur la pertinence de la technologie et des mathématiques dans la préparation à assumer les responsabilités professionnelles d'aujourd'hui.

Pour réitérer les propos de notre premier éditorial, il serait juste de dire que les défis actuels de la formation infirmière sont effectivement nombreux, complexes et variés. Le monde change, et c'est pourquoi la formation infirmière subit des transformations, surtout à la lumière de ce que l'on pourrait décrire comme un tsunami de technologies (Caplan, Myrick, Smitten et Kelly, 2014). L'engagement dans un dialogue scientifique est plus que jamais crucial à notre développement comme infirmières formatrices si nous voulons être en mesure de relever les 
défis nombreux et complexes que pose le monde d'aujourd'hui. Nous vous invitons à participer de façon passionnée, attentive, éclairée et réfléchie, tout en faisant preuve d'ouverture d'esprit.

Nous nous réjouissons à l'idée de poursuivre notre riche dialogue sur les avancées en formation infirmière.

Co-Editors-in-Chief / Les co-rédactrices-en-chef

Florence Myrick, RN, PhD, Faculty of Nursing, University of Alberta

Jacinthe Pepin, inf., Ph.D., Faculté des sciences infirmières, Université de Montréal

\section{References / Références}

Caplan, W., Myrick, F., Smitten, J., \& Kelly, W. (2014). What a tangled web we weave: How technology is re-shaping pedagogy. Nurse Education Today, 34(8), 1172-1174.

http://dx.doi.org/10.1016/j.nedt.2014.04.005 